University of Thi-Qar Journal Vol.10 No.4 Dec 2015

Web Site: https://jutq.utq.edu.iq/index.php/main Email: journal@jutq.utq.edu.iq

\title{
Assessment of Dietary Pattern for Diabetic Patients type2 who attended Al Nasiriyha Diabetes and Endocrinology Center
}

\author{
https://doi.org/10.32792/utq/utj/vol10/4/2
}

\begin{abstract}
Qassim A. Khasal, MSc
Assistant lecturer, Department of Adult nursing, College of Nursing ,university of Thi-Qar
\end{abstract}

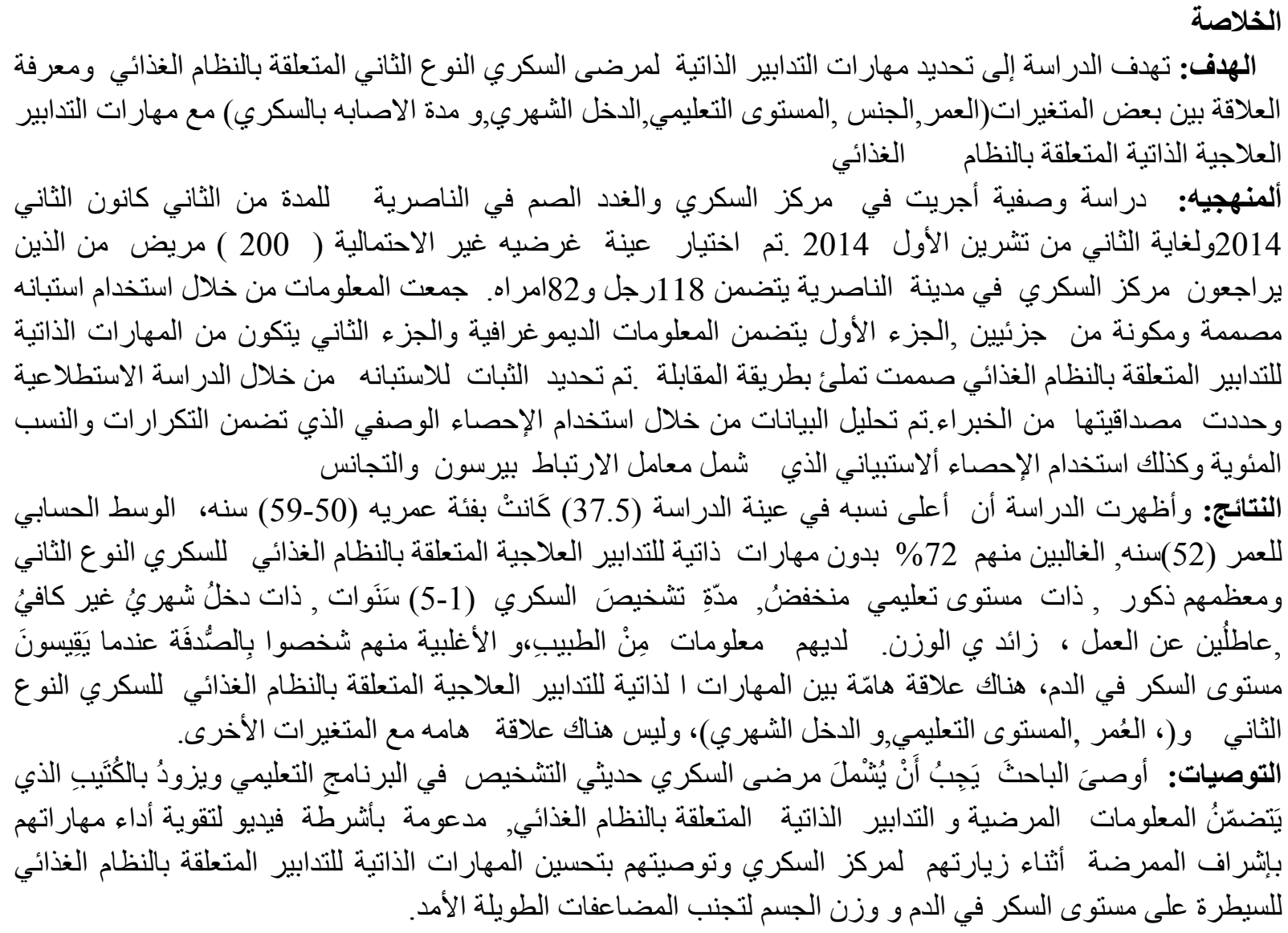

\section{Summary}

Objective: study aims to identify the diabetes type 2 patients self management skills toward dietary pattern , and find out the relationship between variables which are (Age, gender, educational level, duration of diabetes diagnosis, and monthly income) with diabetes type 2 patients self management skills toward dietary pattern

Methodology: descriptive study was carried out through the present investigation from January $2^{\text {nd }} 2014$ to September $2^{\text {nd }} 2014$ in order to achieve the objectives of the present study. A non probability (purposive) sample, (200) cases which consists of patients who were attending Al-Nasiriyha diabetic center. Including (118) males and (82) females . The data were collected by utilization of the study instruments and employment of scheduled interview 
as means data collection. The data collection process was performed from April / 30/ 2014 to Jun / $3^{\text {rd }} / 2014$. A questionnaire was constructed to measure the variable. Such a construction was done through the review of literature and related studies. The questionnaire consisted of 2 parts which are demographical, and diabetics self management skills indicator dietary pattern. The reliability of the questionnaire was determined through a pilot study and the validity through a panel of experts. The data were analyzed through the application of descriptive statistic frequency, percentage, and the application of inferential statistical procedures, which include Pearson correlation coefficient, and contingency coefficient.

Results: Highest age group of the study samples (37.5) were (50-59) years old. with the mean age (52) years, (72.0) of them are without of diabetes type 2 self management skills toward dietary pattern, most of them were male. With low educational level. group's duration of type 2 DM diagnosis was (1-5) years. insufficient monthly income, unemployed, overweight. they had information from their physician, and diagnosed by chance. There are significant association between patients self management skills toward dietary pattern and (age, educational level, monthly income).No result was show.

The researcher recommended that the new diabetic patients should be involve in educational program, supply with booklet which include self management skills toward dietary pattern and supported by videotapes to enforce their practices, with the nurse supervision during visit to the center, and instructed to improve their life management skills for control their blood glucose and body weight to avoid long term complications.

Keywords: Assessment, diabetes type 2, patients, self management skills, dietary pattern.

\section{Introduction:}

Diabetes Mellitus (DM) is a group of metabolic diseases characterized by hyperglycemia resulting from defects in insulin secretion, action, or both. The chronic hyperglycemia is associated with Long-term damage, dysfunction, and failure of various organs especially the eyes, kidneys, nerves, heart, and blood vessels, DM is a much talked about subject these days. It is thought to be one of diseases with a rapid increase in prevalence in the world to the extent the World Health Organization (WHO) described it as an epidemic disease $^{(1)}$. It is requires kills with knowledge in using evidence-based advances in treatment and self management skills ${ }^{(2)}$.

Life skills are Practices used in every day to maintain a healthy self skills management toward dietary pattern with DM which allow patients to operate independently at home, and help them to control blood glucose level, it helps clients to exposed to various skills that will be face the challenges in future, To restore, prevent, treat, delayed, and decrease complications ${ }^{(3)}$. By glycemic control in patients with diabetes type2, these benefits have been demonstrated in multiple large trials \& available. with self management skills can minimize risk of complications through blood glucose level and lipids target which are significant of DM patients type 2 to improves and engorgement of patient's performance ${ }^{(4)}$

\section{Importance of the Study:}

Given the high prevalence of diabetes mellitus in the Iraqi adult population; the development of life management skills for the patient with diabetes must play a major role to 
University of Thi-Qar Journal Vol.10 No.4 Dec 2015

Web Site: https://jutq.utq.edu.iq/index.php/main Email: journal@jutq.utq.edu.iq

improve compliance and control complications. The findings from this study can provide essential data to help in the development of interventions to enhance the patient's life management skills and behaviors.

\section{Objectives of the Study are to:}

1. of dietary pattern for Diabetic 2 Patients.

2. To find out the relationship between (age, gender, educational level, duration of DM diagnosis, and monthly income) in relationship to patients self Management skills toward dietary pattern.

\section{Methodology:}

descriptive study was carried out through the present investigation from January $2^{\text {nd }} 2014$ to September $2^{\text {nd }} 2014$ in order to achieve the objectives of the present study.

An official permission was obtained from the ministry of planning ICentral Council of Statistics for the acceptance of the questionnaire draft. Another approval is issued from the Ministry of Health\The study has been conducted on the diabetes type 2 clients who are attended Al Nasiriyha Diabetic and Endocrinology Center. A non probability (purposive) sample, (200) cases. Including (120) males and (80) females .

A non probability purposive sample of 200 cases which consists of clients who were attending AlNasiriyha Diabetic and Endocrinology Center. Including 118 male 82 femal with the mean of age $(19.5, \pm 9.25)$ year. The results according to the following criteria:

Inclusion Criteria:

1:Men and women who were diagnosed With diabetes type 2 .

2:Ages between 20 - 69 years old.

Exclusion Criteria:

3: Free from other systemic illnesses.

4: Free from psychiatric illnesses.

5: Duration of diabetes mellitus not less than one year.

6: Excluded pregnant women with diabetic during pregnancy.

A questionnaire was designed and constructed by the researcher to measure the study variables. Such a construction was employed through the review of literature and related studies. The questionnaire consisted of two parts which are demographic and diabetic life skills indicators.

Part I:

Demographic information: (6 items) age, gender, marital status, educational level, occupation, income in month was calculated as Socio Economic Status Scale (SES).

Clinical information: (4 items) how diabetes was diagnosed, duration of diabetes, body mass index, source of diabetes knowledge. The total (10 items), the next diabetes life skills indicator,

Part II: Dietary patterns (11 items).

The questionnaire items were rated and scored and rated on a scale of close-ended responses Yes $=2 \mathrm{No}=1$, where the lowest score represents a deficit of diabetes life skills 
University of Thi-Qar Journal Vol.10 No.4 Dec 2015

Web Site: https://jutq.utq.edu.iq/index.php/main Email: journal@jutq.utq.edu.iq

while the highest score represents having diabetes life skills, for the final analysis all points are summed up.

The maximum score is from (summation number of items X2)

The minimum point is from (summation number of item $\mathrm{X} 1$ )

Maximum score to cut point $=$ have diabetes life skills.

Minimum score to cut point $=$ deficit diabetes life skills.

The body mass index (BMI) is calculated by dividing the weight in kilograms by the square of the height in meters.

$\mathrm{BMI}=$ Body weight in kilogram $/$ Height in (meter) and determined according to (BMI) classifications.

$\leq 18.5 \mathrm{~kg} / \mathrm{m} 2$ under weight

$18.5-24.9 \mathrm{~kg} / \mathrm{m} 2$ normal

$25.0-29.9 \mathrm{~kg} / \mathrm{m} 2$ over weight.

$30.0-39.9 \mathrm{~kg} / \mathrm{m} 2$ obese.

$\geq 40.0 \mathrm{~kg} / \mathrm{m} 2$ morbid obese ${ }^{(10)}$.

SES=121-150 High score. SES=90-120 Middle score. SES=89 and less low score ${ }^{(11)}$.

The content validity for the earlier constructed instrument was determined through a panel of experts of investigate the content of the questionnaire for clarity and adequacy in order to achieve the objectives of the present study.

A purposive sample of 20 male and femal with diabetes type 2 who attended $\mathrm{Al}$ Nasiriyha Diabetic and Endocrinology Center. The pilot study was conducted from 2 / March / 2014 to 21 /Aprils / 2014.

Reliability was determined through a computation of Pearson's correlation for scale coefficients $r=0.90$.

$r=0.89$ for special life skills concerning dietary pattern questionnaire.

The data were collected in two ways for the present study through the utilization of the study instruments and employment of a scheduled interview as a means for data collection. The data collection process was performed from April / 30/ 2014 to jun / $3^{\text {rd }} / 2014$

Interviews by the use of the questionnaire took approximately arrange 15 to 20 minutes for each patient.

The research measured height and weight for each patient and calculated BMI for classification.

Analysis of the data was employed through the application of the following statistical data analysis approaches.

Descriptive statistical dataanalysis: including ( Frequency $=($ F), Percentage , Mean, SD) and inferential statistical data analysis person correlation coefficient.

\section{Results:}

Table 1: Demographic characteristics of (200) diabetic patients type 2

\begin{tabular}{|l|l|l|}
\hline Age & $\begin{array}{l}\text { Frequency } \\
\mathrm{n}=200\end{array}$ & Percent100\% \\
\hline $20-29$ years & 18 & 9.0 \\
\hline
\end{tabular}


University of Thi-Qar Journal Vol.10 No.4 Dec 2015

Web Site: https://jutq.utq.edu.iq/index.php/main Email: journal@jutq.utq.edu.iq

\begin{tabular}{|c|c|c|}
\hline $30-39$ years & 24 & 12.0 \\
\hline $40-49$ years & 38 & 19.0 \\
\hline $50-59$ years & 75 & 37.5 \\
\hline $60-69$ years & 45 & 22.5 \\
\hline Gender & Frequency & Percent $\%$ \\
\hline Man & 118 & 59.0 \\
\hline Woman & 82 & 41.0 \\
\hline Marital status. & Frequency & Percent $\%$ \\
\hline Single & 33 & 16.5 \\
\hline Married & 144 & 72.0 \\
\hline Widowed & 6 & 3.0 \\
\hline Divorce & 17 & 8.5 \\
\hline Educational level. & Frequency & Percent $\%$ \\
\hline 11litreate & 79 & 39.5 \\
\hline Read and write & 20 & 10.0 \\
\hline Primary school graduate & 30 & 15.0 \\
\hline Intermediate school graduate & 18 & 9.0 \\
\hline Secondary school graduate & 20 & 10.0 \\
\hline High institute graduate. & 18 & 9.0 \\
\hline College graduate and above & 15 & 7.5 \\
\hline Duration of diabetes mellitus diagnosis. & Frequency & Percent $\%$ \\
\hline $1-5$ years & 88 & 44.0 \\
\hline $6-10$ years & 62 & 31.0 \\
\hline 11 years and above & 50 & 25.0 \\
\hline Monthly income. & Frequency & Percent $\%$ \\
\hline Sufficient & 4 & 2.0 \\
\hline Barely sufficient & 43 & 21.5 \\
\hline Insufficient & 153 & 76.5 \\
\hline Occupation. & Frequency & Percent $\%$ \\
\hline Employee & 66 & 33.0 \\
\hline Unemployed & 76 & 38.0 \\
\hline House wife & 58 & 29.0 \\
\hline Body mass index ( BMI ). & Frequency & Percent $\%$ \\
\hline Under weight (Less than $<18.5 \mathrm{~kg} / \mathrm{m}^{2}$ & 2 & 1.0 \\
\hline Normal weight $(18.5-24.9) \mathrm{kg} / \mathrm{m}^{2}$ & 61 & 30.5 \\
\hline Over weight $(25.0-29.9) \mathrm{kg} / \mathrm{m}^{2}$ & 99 & 49.5 \\
\hline Obese $(30.0-39.9) \mathrm{kg} / \mathrm{m}^{2}$ & 38 & 19.0 \\
\hline
\end{tabular}

Table. 1 indicates that $(37.5 \%)$ of age groups are $(50-59),(59.0 \%)$ were male, $(72.0 \%)$ were married, $(39.5 \%)$ of the groups do not read and write, (44.0\%) groups of 
University of Thi-Qar Journal Vol.10 No.4 Dec 2015

Web Site: https://jutq.utq.edu.iq/index.php/main Email: journal@jutq.utq.edu.iq

duration of DMtype2 diagnosis at (1-5) years, (76.5\%) are insufficient monthly income, $(38.0 \%)$ are unemployed , $(49.5 \%)$ of the group are overweight .

Table 2: Total of (200) diabetes type 2 clients' self-care skills toward blood glucose level control.

\begin{tabular}{|l|l|l|l|}
\hline Clients count & $\begin{array}{l}\text { Without self-care } \\
\text { skills }\end{array}$ & With self-care skills & Total \\
\hline Count & 144 & 56 & 200 \\
\hline$\%$ of total & $72.0 \%$ & $28.0 \%$ & $100.0 \%$ \\
\hline
\end{tabular}

This table indicates that $(72.0 \%)$ of the study sample were without diabetes type 2 self-care skills toward dietary pattern. , while $(28.0 \%)$ of the study sample were with diabetes type 2 patients self management skills toward dietary pattern.

Table 3: Mean scores for items of (200) diabetes type 2 patients self management skills toward dietary pattern.

\begin{tabular}{|l|l|l|l|l|l|}
\hline No. & Items & $\begin{array}{l}\text { Score } \\
\text { yes }\end{array}$ & $\begin{array}{l}\text { Score } \\
\text { No. }\end{array}$ & M.S & \\
\hline $1-$ & $\begin{array}{l}\text { Do you take small meals and frequent (5-6) } \\
\text { meals daily. }\end{array}$ & 95 & 105 & 1.47 & $\mathrm{~L}$ \\
\hline $2-$ & Do you take rich fiber vegetables. & 44 & 156 & 1.22 & $\mathrm{~L}$ \\
\hline $3-$ & Do you avoid eating red meat e.g. (beef, sheep) & 100 & 100 & 1.50 & $\mathrm{M}$ \\
\hline $4-$ & Do you take white meat e.g. (chicken, fish). & 159 & 41 & 1.79 & $\mathrm{M}$ \\
\hline $5-$ & Do you avoid rich fatty foods & 115 & 85 & 1.57 & $\mathrm{M}$ \\
\hline $6-$ & $\begin{array}{l}\text { Do you avoid foods rich with sugar e.g. (sweets). } \\
\text { Do you avoid taking soft carbonate beverage. }\end{array}$ & 711 & 89 & 1.55 & $\mathrm{M}$ \\
\hline $7-$ & $\begin{array}{l}\text { Do you avoid taking foods outside home e.g. } \\
\text { (restaurant). }\end{array}$ & 71 & 129 & 1.38 & $\mathrm{~L}$ \\
\hline $8-$ & $\begin{array}{l}\text { Do you avoid use sweetam instead of the normal } \\
\text { sugar to sweet the tea. }\end{array}$ & 62 & 138 & 1.31 & $\mathrm{~L}$ \\
\hline $9-$ & $\begin{array}{l}\text { Do you avoid taking much fruit especially } \\
\text { (grape). }\end{array}$ & 87 & 113 & 1.43 & $\mathrm{~L}$ \\
\hline 10 & Do you increase taking (Limon). & 104 & 96 & 1.52 & $\mathrm{M}$ \\
\hline 11 & Total & 1176 & 1.46 & $\mathrm{~L}$ \\
\hline
\end{tabular}

Table 3 indicates that the mean of scores are moderate for the items $(3,4,5,6$, and 11) and the remaining $(1,2,7,8,9,10$ and the total) are low. 
University of Thi-Qar Journal Vol.10 No.4 Dec 2015

Web Site: https://jutq.utq.edu.iq/index.php/main Email: journal@jutq.utq.edu.iq

Table 4: Association between educational level and diabetes life skill

\begin{tabular}{|c|c|c|c|c|c|c|c|}
\hline \multicolumn{2}{|c|}{ Age } & $\begin{array}{l}\text { Without } \\
\text { life skills }\end{array}$ & $\begin{array}{l}\text { With life } \\
\text { skills }\end{array}$ & Total & $\begin{array}{l}* \\
\text { C. C } \\
\text { test }\end{array}$ & $\begin{array}{l}* * \\
\mathrm{P}- \\
\text { valu } \\
\mathrm{e}\end{array}$ & $\begin{array}{l}* * * \\
\mathrm{CS}\end{array}$ \\
\hline \multirow{2}{*}{$20-29$ years. } & $\mathrm{F}$ & 11 & 7 & 18 & \multirow{10}{*}{0.233} & 0.02 & \multirow[t]{10}{*}{$\mathrm{S}$} \\
\hline & $\%$ & 5.5 & 3.5 & 9.0 & & \multirow[t]{9}{*}{2} & \\
\hline \multirow[t]{2}{*}{$30-39$ years. } & F & 15 & 11 & 24 & & & \\
\hline & $\%$ & 6.5 & 5.5 & 12.0 & & & \\
\hline \multirow[t]{2}{*}{$40-49$ years. } & $\mathrm{F}$ & 26 & 12 & 38 & & & \\
\hline & $\%$ & 13.0 & 6.0 & 19.0 & & & \\
\hline \multirow[t]{2}{*}{$50-59$ years. } & $\mathrm{F}$ & 54 & 21 & 75 & & & \\
\hline & $\%$ & 27.0 & 10.5 & 37.5 & & & \\
\hline \multirow[t]{2}{*}{$60-69$ years. } & F & 40 & 5 & 45 & & & \\
\hline & $\%$ & 20.0 & 2.5 & 22.5 & & & \\
\hline \multirow[t]{2}{*}{ Total } & $\mathrm{F}$ & 144 & 56 & 200 & & & \\
\hline & $\%$ & $72.0 \%$ & $28.0 \%$ & $100.0 \%$ & & & \\
\hline \multicolumn{8}{|c|}{ Contingency level $=0.978$} \\
\hline
\end{tabular}

${ }^{*} \mathrm{CC} .=$ Contingency coefficient. $(* * \mathrm{P}-$ value $<0.05) . * * * \mathrm{CS}=$ Comparative Significant. $\mathrm{S}=$ significant

Table 4 shows that there is a significant relationship between diabetes type 2 self management skills with age. 
University of Thi-Qar Journal Vol.10 No.4 Dec 2015

Web Site: https://jutq.utq.edu.iq/index.php/main Email: journal@jutq.utq.edu.iq

Table 5: Association between educational level and diabetes life skill

\begin{tabular}{|c|c|c|c|c|c|c|c|}
\hline \multicolumn{2}{|c|}{ Total diabetes life skills } & $\begin{array}{l}\text { Without } \\
\text { life skills }\end{array}$ & $\begin{array}{l}\text { With life } \\
\text { skills }\end{array}$ & Total & $\begin{array}{l}* \\
\text { C. C } \\
\text { Test }\end{array}$ & $\begin{array}{l}* * \\
\mathrm{P}-\text { value }\end{array}$ & C.S \\
\hline \multirow[t]{2}{*}{ Illiterate } & $\mathrm{F}$ & 69 & 10 & 79 & \multirow[t]{16}{*}{0.445} & \multirow[t]{16}{*}{0.000} & \multirow[t]{16}{*}{ S } \\
\hline & $\%$ & 34.5 & 5.0 & 39.5 & & & \\
\hline \multirow[t]{2}{*}{ Read and write } & $\mathrm{F}$ & 18 & 2 & 20 & & & \\
\hline & $\%$ & 9.0 & 1.0 & 10.0 & & & \\
\hline \multirow{2}{*}{$\begin{array}{ll}\text { Primary } & \text { school } \\
\text { graduate } & \end{array}$} & $\mathrm{F}$ & 24 & 6 & 30 & & & \\
\hline & $\%$ & 12.0 & 3.0 & 15.0 & & & \\
\hline \multirow{2}{*}{$\begin{array}{l}\text { Intermediate } \\
\text { school graduate }\end{array}$} & $\mathrm{F}$ & 13 & 5 & 18 & & & \\
\hline & $\%$ & 6.5 & 2.5 & 9.0 & & & \\
\hline \multirow{2}{*}{$\begin{array}{l}\text { Secondary School } \\
\text { graduate }\end{array}$} & $\mathrm{F}$ & 11 & 9 & 20 & & & \\
\hline & $\%$ & 5.5 & 4.5 & 10.0 & & & \\
\hline \multirow{2}{*}{$\begin{array}{l}\text { High institute } \\
\text { graduate }\end{array}$} & $\mathrm{F}$ & 4 & 14 & 18 & & & \\
\hline & $\%$ & 2.0 & 7.0 & 9.0 & & & \\
\hline \multirow{2}{*}{$\begin{array}{l}\text { College graduate } \\
\text { and above }\end{array}$} & $\mathrm{F}$ & 5 & 10 & 15 & & & \\
\hline & $\%$ & 2.5 & 5.0 & 7.5 & & & \\
\hline \multirow[t]{2}{*}{ Total } & $\mathrm{F}$ & 144 & 56 & 200 & & & \\
\hline & $\%$ & 72.0 & 28.0 & 100.0 & & & \\
\hline
\end{tabular}

$*$ CC. $=$ Contingency coefficient. $(* * \mathrm{P}-$ value $<0.05) . * * * \mathrm{CS}=$ Comparative Significant.

$\mathrm{S}=$

significant

Table 5 present that there are a significant relationship between educational level with total diabetes type 2 clients self management skills.

Table6: Association between monthly income and diabetes life skill

\begin{tabular}{|c|c|c|c|c|c|c|c|}
\hline \multicolumn{2}{|c|}{ Motal diabetes life skills } & $\begin{array}{l}\text { Without } \\
\text { life skills }\end{array}$ & $\begin{array}{l}\text { With life } \\
\text { skills }\end{array}$ & Total & $\begin{array}{l}* \\
\text { C. C. } \\
\text { Test }\end{array}$ & $\begin{array}{l}* * \\
\text { P- value }\end{array}$ & C.S \\
\hline \multirow[t]{2}{*}{ Sufficient } & $\mathrm{F}$ & 1 & 3 & 4 & \multirow[t]{8}{*}{0.283} & \multirow[t]{8}{*}{0.000} & \multirow[t]{8}{*}{$\mathrm{S}$} \\
\hline & $\%$ & 0.5 & 1.5 & 2.0 & & & \\
\hline \multirow[t]{2}{*}{ Barley sufficient } & $\mathrm{F}$ & 22 & 21 & 43 & & & \\
\hline & $\%$ & 11.0 & 10.5 & 21.5 & & & \\
\hline \multirow[t]{2}{*}{ Insufficient } & $\mathrm{F}$ & 121 & 32 & 153 & & & \\
\hline & $\%$ & 60.5 & 16.0 & 76.5 & & & \\
\hline \multirow[t]{2}{*}{ Total } & $\mathrm{F}$ & 144 & 56 & 200 & & & \\
\hline & $\%$ & 72.0 & 28.0 & 100.0 & & & \\
\hline
\end{tabular}

$* \mathrm{CC} .=$ Contingency coefficient. $(* * \mathrm{P}-$ value $<0.05) . * * * \mathrm{CS}=$ Comparative

Significant. $\mathrm{S}=$ significant 
University of Thi-Qar Journal Vol.10 No.4 Dec 2015

Web Site: https://jutq.utq.edu.iq/index.php/main Email: journal@jutq.utq.edu.iq

This table indicates there are a significant relationship between total diabetes type 2 clients self management skills toward dietary pattern with monthly income.

\section{Discussion: This study content of three parts which include:}

\section{Part I:}

Discussion of (200) diabetes type 2 client's demographic characteristics distribution.

Table 1: Indicated that the finding of the present study revealed that the sample age group between (20-69) years and the majority 75 (37.5\%) of the group were (50-59) years, the mean of age are (52) years. This finding is supported by Boon et al ${ }^{(14)}$. Whose reported that the type $2 \mathrm{DM}$ is principally a disease of the middle aged and elderly. In the U.K, it affected $(10 \%)$ of population over 65 years, and over $(70 \%)$ of all cases of DM occur after of 50 years .And similar to the result, obtained from study done by Al-Mansour ${ }^{(15)}$. stated that the mean age was higher at (52) years old among clients who attended the out-patient clinic in AlFaiha hospital in Basrah in both sex.

Related to gender the majority $118(59.0 \%)$ of study sample are males and the remaining are females. This results are similar to result obtain from study done by AlMansour ${ }^{(15)}$. While the option views of the researcher the male $\&$ female have an equal chance to expose to diabetic disease. Concerning to marital status, the majority $144(72.0 \%)$ of study sample were married, while the minority $6(3 \%)$ were widowed. This finding is agree with study done by Al-Suffar ${ }^{(16)}$.stated that the majority $(83 \%)$ of the study sample are married.

With regard to the level of education of type 2 diabetic client, it is demonstrated that most of them could not read \& write and they a counted 79 (39.5\%) for the study sample. This result was agree with results obtain from study done by Musaiger \& Al-Mannai ${ }^{(17)}$. Who's found that the educational level among Bahraini adults with type 2 DM did not read and write.

Relative duration since DM diagnosing, the majority 88 (44\%) of the study sample are in duration of (1-5) years, while the minority $50(25 \%)$ are in duration (11) years and above, while the range between (1-11) years and above, the mean is (7.05). These results was supported results obtain from study done by Akbal ${ }^{(18)}$. stated that the mean of diabetes type 2 clients duration averaged (9.8) years.

Regarding income most of the study sample $153(76.5 \%)$ is insufficient and most of them $76(38 \%)$ are unemployed. This result is supported with study done by Maxwell et al (10). stated that more than $(44 \%)$ of their study sample were retired and significantly associated with diabetes self-care skills.

Related to BMI the majority $99(49.5 \%)$ of the study sample are (25.0-29.9) kg / m2 they are overweight. This result is supported with results obtain from study done by AlMansour ${ }^{(6)}$. stated that type $2 \mathrm{DM}$ is strongly associated with obesity, more than $(80 \%)$ of adults are overweight or obese.

Relative to knowledge about DM disease, the majority $182(91 \%)$ of the study sample have knowledge, most of them $148(74 \%)$ the sources of information from their physicians and $24(12 \%)$ from nurses, and the minority $18(9 \%)$ haven't knowledge about diabetes life skills. This result agrees with study done by Maxwell ${ }^{(19)}$. Reported that appropriate patients 
knowledge from health care provider team for self-care skills are the key to achieving therapeutic goals in ambulatory care. These finding means that the nurse play inadequate role in giving information diabetes patient against to my literature which emphases on the role of nurse to educate the patient with chronic illness about his or her disease (The researcher).

Relative to how DM has been diagnosed the majority 75 (37\%) of the study sample are diagnosed incidentally when measuring BG level, while the minority $47(23.5 \%)$ are diagnosed when polyurea and mouth dryness appears. This result is supported with results obtain from study done by American Diabetic Association (ADA) ${ }^{(20)}$. stated that for most patients approximately (75\%), type 2 DM is detected incidentally (e.g. when routine laboratory test or ophthalmoscope examination are performed. These finding means that the diagnoses of patient with type 2 DM was discover incidentally during BG monitoring or when the patient suffer from complications of the disease (The Researcher).

Table 2: Indicates that the majority 144 (72\%) of the total of (200) diabetes type 2 clients are without DM self management skills toward dietary pattern and the minority (28\%) are with self management skills. This result disagree with study done by National Center for Chronic Disease prevention and Health promotion (NCCDPHP) ${ }^{(21)}$. Reported that the percentage of patients who get recommended preventive services and DM self-care skills, were increased from $(46 \%-87 \%)$ for A1C test, from (19\% - 43\%) for eye exams, from $(26 \%-56 \%)$, for foot exam, from $(36 \%-88 \%)$ for follow-up and from BMI calculated increased from (59\% $73 \%)$.

Table 3: This analysis include (11) items on scale of yes (2) and No (1). This results indicates that the mean of scores are moderate on items $(3,4,5,6,11)$ while low on items $(1,2,8,9$, 10 , and total of dietary pattern skills).

Low mean of scores on item (1) with take small meals and frequent (5-6) meals daily. This finding disagree with results obtain from study done by Juhasz et al ${ }^{(13)}$. stated that one of life skills preventing hypoglycemia is eat at least every (4-5) hours while awake.

Low mean of scores on item (2) with take rich fiber vegetable, and item (10) with avoid taking much fruit especially (grape). This results disagree with results obtain from study done by Jas ${ }^{(14)}$.stated that a diabetic patients must eat a lot of fruits e.g. (Kiwi fruit, apples) with avoid grape due to high in fructose can cause Blood Glucose level to rise quickly, and vegetables, in which fiber content is very high, such as (carrot, tomato, cabbage and cucumber) that is mean more chromium, which is very helpful in the treatment of diabetes. This finding related to inadequate information concerning type of food which must be taking by diabetic patients (The Researcher).

Moderate mean of scores in regard on items $(3,4)$ with avoid eating red met (e.g. beef, sheep), and take white meat (e.g. chicken, fish). This results agree with results obtain from study done by Wilett ${ }^{(15)}$. stated that avoid read meat due to increased risk (HD), while white meat must be eaten such as fish and chicken to improve cholesterol levels.

Moderate mean of scores in regard of item (5) with avoid rich fatty foods. This finding agree with results obtain from study done by Wilett ${ }^{(15)}$. Stated that perhaps the only food that are truly avoid, it's able to cause healthy damaging type of fat.

In regard of item (8) low mean of scores with avoid taking foods outside home (e.g. restaurants). This finding disagree with results obtain from study done by ${ }^{(24)}$. WIN stated that 
the protein size that you get away from home at restaurant grocery store, may contain more food than they need to eat in one sitting, and avoid fast food restaurant.

Low mean of scores in regard on items $(7,9)$ avoid taking soft carbonate beverage, and avoid use. Sweet is instead of the normal sugar to sweet the tea. This finding disagree with results obtain from study done by 24 (Jas, 2011) who stated that the diabetes patients must be avoid fruit juices, and the meal with sugar sweet tea.

Moderate mean of scores on item (6) with avoid foods rich with sugar (e.g. sweets) . This finding agree with results obtain from study done by Mercola ${ }^{(26)}$.stated that an in-depth of artificial sweeteners-it can seriously harm the patients, a new study will hopefully convince patients to avoid products that content artificial sweeteners. This finding may be related to strong desire of diabetic patient to lake sweet diet (The Researcher).

Moderate mean of scores on item (11) with increase taking lemon. This result agree with results obtain from study done by Jacob ${ }^{(27)}$.stated that vitamin $\mathrm{C}$ which is found in citrus fruits (e.g. lemon, orange), is recommended in diabetics due to play crucial role in reducing all problem face diabetics patient such as (gum problem, muscles weakness, and delayed wound healing and it can protect from sever DM complications.

Low mean of scores on total (200) diabetes type 2 life skills concerning dietary pattern. This finding disagree with results obtain from study done by Boon et al ${ }^{(5)}$.stated that the diet and lifestyle advice alone or of three methods of treatment are available for diabetic patients, approximately $50 \%$ of new cases of type $2 \mathrm{DM}$ can be controlled adequately by diet alone.

Table 4: Indicates that there is a significant relationship between age and diabetes type 2 self management skills toward dietary pattern $(C . C=0.233, C . L=0.978)$. This results agree with results obtain from study done by Baquedano et a ${ }^{(19)}$ stated that self-care skills ability in relation to age group, the following presented good self-care skills ability $25(10 \%)$ between (50-59) years of age, while (0.4\%) between (30-39) years of age.

Table 5: Indicates that there is a significant relationship between educational level and diabetes type 2 , clients self management skills toward dietary pattern (C.C $=0.455$, C.L $=$ $1.000)$ The majority (34.5\%) of the study sample are do not read and write without diabetes type 2 life skills This results were similar to results obtain from study done by Baquedano et $\mathrm{al}^{(19)}$ indicated that there is a significant relationship between level of education and self-care skills. Which mean that level of education effect of reduce practice of multiple self-care skills among less educational level patients (The researcher)

Table 6: Indicates that there is a significant relationship between monthly income and diabetes type 2 clients self management skills toward dietary pattern (C.C $=0.283$, C.L $=$ $1.000)$, furthermore indicates that $(60.5 \%)$ of the study sample with insufficient monthly income without diabetes life skills. This results agree with results obtain from study done by Arleen et $\mathrm{al}^{(20)}$.stated that a high income is the highest complications free rate. $(54.1 \%)$ and lowest multiple complications (8.1\%) three or more complications compared to those in the lowest socioeconomic status (SES) group (22\%) no complications, $(26 \%)$ three or more complications . 
University of Thi-Qar Journal Vol.10 No.4 Dec 2015

Web Site: https://jutq.utq.edu.iq/index.php/main Email: journal@jutq.utq.edu.iq

\section{Recommendation:}

The researcher recommended that the new diabetic patients should be involve in educational program, supply with booklet which include self management skills toward dietary pattern and supported by videotapes to enforce their practices, with the nurse supervision during visit them to the center, and instructed to improve their life management skills for control their blood glucose and body weight to avoid long term complication .

\section{Recommendation:}

The researcher recommended that newly diagnosed diabetic patients should be engage in educational program \& supply by booklet which include self-care skills toward blood glucose level control and supported by videotapes to enforce their practices with nurse supervision during visit them to the center to improve their self-care skills.

\section{References:}

\section{References:}

1-American Diabetes Association (ADA ) : Standards of Medical Care in diabetes ( position statement, diabetes care, 2006, vol.29, No. 1, PP. $4-42$.

2- Seley, Jane J., Weinger Katie ., and Mason, Diano J. Diabetes self-care : A challenge to Nursing . Nursing

P. 1-2.

3- Merville C. \&Marshall J. Overcoming Barriers to Glycemic control in African Americans with Type 2 Diabetes: Benefits of Insulin Therapy. Journal of the National Medical Association. 2011, Vol. 99 , No. 8 , PP . $868-875$

4-American diabetes Association ( ADA ) : Diabetes : Monitoring your blood sugar level . Family Doctor . org. American Academy of Family . Physicians . 2011.

5-Boon, Nicholas A., Colledge, Nicki R., Walker, Brain R., Hunter, John A.A. Chapter 21. Davidson's principles and practice of Medicine . $20^{\text {th }}$ ed . London . Mosby . 2006 , PP. $805-$ 847 .

6- Al-Mansour, A bbase Ali . Opportunistic screening for type 2 diabetes Mellitus in the outpatient clinic . Basra College of Medicine, Basra , Iraq , Available at http://www. priovy . com . 2009.

7-Al-Suffar Nathera Hussein Alwaqn : Assessment of diabetic patient Practices concerning foot care . ( Thesis ) . University of Baghdad, Nursing College, 2002. PP. 86 - 106.

8- Musaiger A. ; Abdurrahman, A. Al- Annie , M. \& Mariam, A. ; Social and lifestyle factors associated with diabetes in the adult Bahraini population ; Biosocial scientific Journal , 2002 , Vol. 34 , No. 2 , PP. 277 - 281.

9-Akbar, D. Zawawi T. Miroe , S. Marzaki , K. \& Hashim I. , Experience of 12 - month therapy with a carbose, glimbenclamide, and metformin in uncontrolled Saudi Type 2 diabetes patients : a_, 2001 , vol. 11 , No. 1 , PP. $17-35$.

10-Maxwell, Adibe O., Cletus , Aguwan ., and Obinna , Udeogrannap . Diabetes Self-care knowledge among type 2 diabetes out patients in south-Eastern Nigeria . International Journal of Drug Development and research . 2009 , Vol. 1, No. 1, PP. 85 - 104. 
University of Thi-Qar Journal Vol.10 No.4 Dec 2015

Web Site: https://jutq.utq.edu.iq/index.php/main Email: journal@jutq.utq.edu.iq

11- American diabetes Association( ADA ), American psychiatric Association , North American Association for the study of obesity : Consensus development conference on antipsychotic drug and obesity and diabetes . diabetes care . 2004 . Vol. Vol. 27 . PP. 596 601 .

12-National Center for Chronic Disease prevention and Health promotion (NCCDPHP) Diabetes: Successes and opportunities for population - Based prevention and Control AT a Glance. 2011, P.P. 1 - 10. Available at http//:www.cdc.gov/diabetes.

13-Juhasz Myra . Robinsen Catherine , April Engel and Chris Will man . Survival skills for Diabetes . Florida Health care Plan . 2010 . Available at http://www. Changing diabetes . us . com .

14-Jas Ashi : diabetes - foods to Eat and Avoid . Ezine articles . 2011 , Available in http://www. Diabetes mellitus-information . com .

15 -Willett Walter. The Nutrition source food Pyramids : What Should you really Eat . Harvard School of public Health 2010 .

16- WIN. Weight-control Information Net work . Take charge of your Health A Guide for teenagers . National institute and digestive and kidney Diseases ( NIDDK ) . 2011 , P.P 1 - 16

17-Mercola Joseph . Artificial sweeteners . An in - depth review of artificial sweeteners because what you don't know about them can seriously harm your . and your family's health Mercola . com . 2009 . Available at http://www. Articles. Mercola . com .

18-Jacobs D. : Vitamin C and diabetes - Benefits of Ascorbic A cid for Diabetics 2010. Available at http://www. All-about- beating - diabetes. Com .

19-Baquedano Irasema Romero, Manoel Antonio dos Santos, Carla Regina De Souza Teixira and Maria Lucia Zanetti : Factors related to self-care in diabetes mellitus patients attebended at emergency Service in Mexico. Rev. Esc Enterm Usp. 2010 , Vol. 44 , NO. 4 , PP. 1013 - 1019. 